Article

\title{
Process analysis of main organic compounds dissolved in aque- ous phase by hydrothermal processing of Açaí (Euterpe Oleraceae, Mart.) seeds: Influence of process temperature and biomass-to-water ratio
}

\author{
Conceição de Maria Sales da Silva ${ }^{3}$, Douglas Alberto Rocha de Castro ${ }^{3}$, Marcelo Costa Santo ${ }^{2}$, \\ Hélio da Silva Almeidaa, , Ulf Lüder ", Maja Shultze 1; Jan Mumme 1; Thomas Hofmann 1, \\ Nélio Teixeira Machado ${ }^{1,2,3 *}$
}

1 Leibnitz-Institüt für Agrartechnik Potsdam-Bornin e.V, Department of Postharvest Technology, Max-EythAlee 100, Potsdam 14469, Germany; atb@atb-potsdam.de

2 Faculty of Sanitary and Environmental Engineering, Rua Corrêa N ${ }^{\circ}$ 1, Campus Profissional-UFPA, BelémPará-Brazil, CEP: 66075-900; faesa@ufpa.br

3 Graduate Program of Natural Resources Engineering of Amazon; Rua Corrêa N ${ }^{\circ}$, Campus ProfissionalUFPA, Belém-Pará-Brazil, CEP: 66075-110, proderna@ufpa.br

4 SunCoal Industries GmbH, Rudolf-Diesel-Straße 15, 14974 Ludwigsfelde, Germany, info@suncoal.com

* Correspondence: machado@ufpa.br; Tel.: +55-91-984620325

\begin{abstract}
This work aims to investigate systematically the influence of process temperature and biomass-to-water ration on the chemical composition of aqueous and gaseous phases and mass production of chemical by hydrothermal processing of Açaí (Euterpe Oleraceae, Mart.) seeds. The hydrothermal carbonization carried out at $175,200,225$, and $250{ }^{\circ} \mathrm{C}, 2{ }^{\circ} \mathrm{C} / \mathrm{min}$, biomass-to-water ratio of $1: 10$, and at $250{ }^{\circ} \mathrm{C}, 2^{\circ} \mathrm{C} / \mathrm{min}$, and biomass-to-water ratios of $1: 10,1: 15$, and 1:20, in technical scale. The chemical composition of aqueous phase determined by GC and HPLC and the volumetric composition of gaseous phase by using an infrared gas analyzer. For constant biomass-to-water ratio of 1:10, the yields of solid, liquid, and gaseous phases varied between 53.39 and $37.01 \%$ (wt.), 46.61 and $59.19 \%$ (wt.), and 0.00 and 3.80\% (wt.), respectively. The yield of solids shows a smooth exponential decay with temperature, while that of liquid and gaseous phases a smooth growth. By variation of biomass-to-water ratios, the yields of solid, liquid, and gaseous reaction products varied between 53.39 and $32.09 \%$ (wt.), 46.61 and $67.28 \%$ (wt.), and 0.00 and $0.634 \%$ (wt.), respectively. The yield of solids decreases exponentially with increasing water-to-biomass ratio and that of liquid phase increases in a sigmoid fashion. For constant biomass-to-water ratio, the concentrations of Furfural and HMF decrease drastically with temperature, reaching a minimum at $250{ }^{\circ} \mathrm{C}$, while that of phenols increases. In addition, the concentrations of $\mathrm{CH}_{3} \mathrm{COOH}$ and total carboxylic acids increase, reaching a maximum at $250{ }^{\circ} \mathrm{C}$. For constant process temperature, the concentrations of aromatics vary smoothly with the temperature. The concentrations of furfural, $\mathrm{HMF}$, and cathecol decrease with temperature, while that of phenols increases. The concentrations of $\mathrm{CH}_{3} \mathrm{COOH}$ and total carboxylic acids decrease exponentially with temperature. Finally, for the experiments with varying water-to-biomass ratios, the productions of chemicals (furfural, HMF, phenols, cathecol, and acetic acid) in the aqueous phase is highly dependent on the biomass-to-water ratio.
\end{abstract}

Keywords: Açaí seeds; hydrothermal carbonization; hot compressed water; process analysis, HMF, Furfural, Acetic Acid, Mass Production.

\section{Introduction}

. Açaí (Euterpe oleracea Mart.) is palm native to the Brazilian Amazon [1]. It has abundant occurrence in the Amazon estuary floodplains [2-3]. The Açaí fruits in nature have a great economic importance for the agroindustry, as well as extractive activities of rural communities of the Brazilian Amazonian state of Pará [4]. The fruit is a small dark-purple, berry-like fruit, almost spherical, weighing between 2.6 to $3.0 \mathrm{~g}$ [5]. It has a diameter 
around 10.0 and $20.0 \mathrm{~mm} \mathrm{[5],} \mathrm{containing} \mathrm{a} \mathrm{large} \mathrm{core} \mathrm{seed/kernel} \mathrm{that} \mathrm{occupies} \mathrm{between}$ $85-95 \%$ (vol./vol.) of its volume [3,6].

By processing/extracting the pulp and skin with warm water to produce a thick, purple-colored juice [3,6], a waste is generated [7-11], the Açaí seeds, a rich lignin-cellulosic residue with great potential to energetic use [8-9, 12]. In the crop years 2016-2017 around 1200-1274 million tons of Açaí fruits were produced in Brazil, being the state of Pará the main producer (94\%), generating large amounts of solid residues, consisting of seeds and fibers [4-9].

The residue of Açaí fruits (seeds + fibers) processing has a fibrous outer layer, containing $46.51 \%$ (wt.) cellulose and 30.31\% (wt.) lignin [11], being the residue (seeds + fibers) composed by $36.13 \%$ (wt.) cellulose, $47.92 \%$ (wt.) lignin, $1.57 \%$ (wt.) ash, and 16.64\% (wt.) extractives [11], representing an important biomass renewable source for energetic applications $[8-9,12]$. In fact, only a few studies investigated systematically the

The thermo-chemical transformation of lignin-cellulose rich biomass with $\mathrm{H}_{2} \mathrm{O}$ in the sub-critical or supercritical state is a promising technique, and the literature reports several studies on the subject [13-46]. Li et. all. [13], applied statistical methods to investigate the role of process conditions (temperature, rection time, biomass-to-water ratio) and chemical raw material characteristics on the physical-chemistry properties hydrothermal carbonization products (solid, liquid, and gas). In addition, Li et. all. [13], reported that most commonly cited hydrothermal carbonization product parameter was solid (hydrochar) yield $(71 \%)$, while little attention has been paid to carbon-related information to the liquid and gaseous phases $(<18 \%)$, which includes the analysis of chemical composition.

In fact, only a few studies investigated systematically the composition of main chemical compounds, such as aromatic-ring compounds (Furfural, HMF, Phenols, Cresols, Cathecol, Guaiacol, etc.) $[14,18,39-41]$, carboxylic acids $\left(\mathrm{HCOOH}, \mathrm{CH}_{3} \mathrm{COOH}, \mathrm{CH}_{3} \mathrm{CH}_{2} \mathrm{COOH}\right.$, $\mathrm{CH}_{3} \mathrm{CH}(\mathrm{OH}) \mathrm{COOH}, \mathrm{CH}_{3} \mathrm{C}(\mathrm{O}) \mathrm{CH}_{2} \mathrm{CH}_{2} \mathrm{COOH}$, etc.) [14, 18, 39-40, 43], alcohols $\left(\mathrm{CH}_{3} \mathrm{OH}\right.$, $\mathrm{CH}_{3} \mathrm{CH}_{2} \mathrm{OH}$ ) [14], and sugars (Glucose, Xylose, Galactose, Fructose, Sucrose, Mannosan, Levoglucosan, etc.) [18, 40,43], and BTEX (Benzene, Toluene, Xylenes, and Ethyl benzene) [41], dissolved in the process water by hydrothermal carbonization of biomass, including the hydrothermal processing of corn Stover [14, 18], Tahoe mix, Pinyon/Juniper, and Loblolly pine wood, sugar bagasse, and rice hulls [18], wheat straw, wheat straw digestate, Poplar, Garapa, massaranduba, and pine wood, $\alpha$-Cellulose, and D-(+)-xylose [39], wheat straw, Poplar, and $\alpha$-Cellulose [40], wheat straw, wheat straw digestate, Poplar, Garapa, massaranduba, and pine wood [41], and Tahoe mix [43]. Recently, Poerschmann et. all. [44], investigated the distribution of main medium molar mass compounds dissolved in process water by hydrothermal carbonization of glucose, fructose and xylose by GC-MS and IC, identifying more than 50 compounds, being the most abundant carboxylic acids (formic, acetic, glycolic, lactic, and levulinic acids) and aromatic-ring compounds (Furfural, 5-(Hydroxymethyl)-2-furfural).

Another process parameter affecting the physical-chemistry properties hydrothermal carbonization products (solid, liquid, and gas) is the water-to-biomass ratio, although only a few studies investigated the influence of water-to-biomass ratio by hydrothermal processing of biomass [], including tomato-pell-waste [26], olive stone [27], microalgae [28], sawdust [29]; banana peels [30], wood ships [25], and corn Stalk [19], but no study has examined it's influence consistently [13], particularly on the composition of main chemical compounds dissolved in the process water.

Açaí (Euterpe oleracea, Mart.) seed is the only fruit specie, whose centesimal and elemental composition is completely different from wood biomass (Poplar, Garapa, massaranduba, Tahoe mix, Pinyon/Juniper, Loblolly pine, and pine wood) [18, 39-41, 43], agriculture residues of cereal grains (corn Stover, corn Stalk, rice hulls, wheat straw), agriculture residues of sugar cane (sugar bagasse) [18]. Although, hydrothermal treatment has been applied to enhance enzymatic hydrolysis of Açaí seeds in aqueous- $\mathrm{H}_{2} \mathrm{SO}_{4}$ at $121{ }^{\circ} \mathrm{C}$ [47], until the moment no systematic study investigated the influence of temperature and 
biomass-to-water ration on the chemical composition of aqueous and gaseous phases and mass production of chemicals by HTC of Açaí seeds in technical scale.

This work aims to investigate systematically the influence of process temperature and biomass-to-water ration on the chemical composition of main chemical compounds, such as aromatic-ring compounds, carboxylic acids, and alcohols, dissolved in process water, the gaseous phase composition, and mass production of chemicals by hydrothermal processing of Açaí (Euterpe Oleraceae, Mart.) seeds in technical scale.

\section{Materials and Methods}

\subsection{Materials, pre-treatment, and centesimal/elemental characterization of Açaí (Euterpia oleraceae, Mart.) seeds in nature}

The charges of Açaí (Euterpe oleracea Mart.) seeds in nature obtained in a small store of Açaí commercialization, located in the City of Belém-Pará-Brazil [12]. The seeds were dried at $105{ }^{\circ} \mathrm{C}$, grinded using a knife cutting mill, and sieved using an 18 Mesh sieve, as reported elsewhere [12]. Afterwards, the seeds were physical-chemistry characterized for moisture (AOAC 935.29), volatile matter (ASTM D 3175-07), ash (ASTM D 3174-04), fixed carbon (ASTM D6316-09), lipids (AOAC 963.15), proteins (AOAC 991.20) according to official methods [12], fibers determined according to a standard norm [48], and insoluble lignin by the modified method of Klason [49].

\subsection{Experimental apparatus and procedures}

2.2.1. Experimental apparatus [14].

The technical scale apparatus illustrated in Figure 1, described in details elsewhere

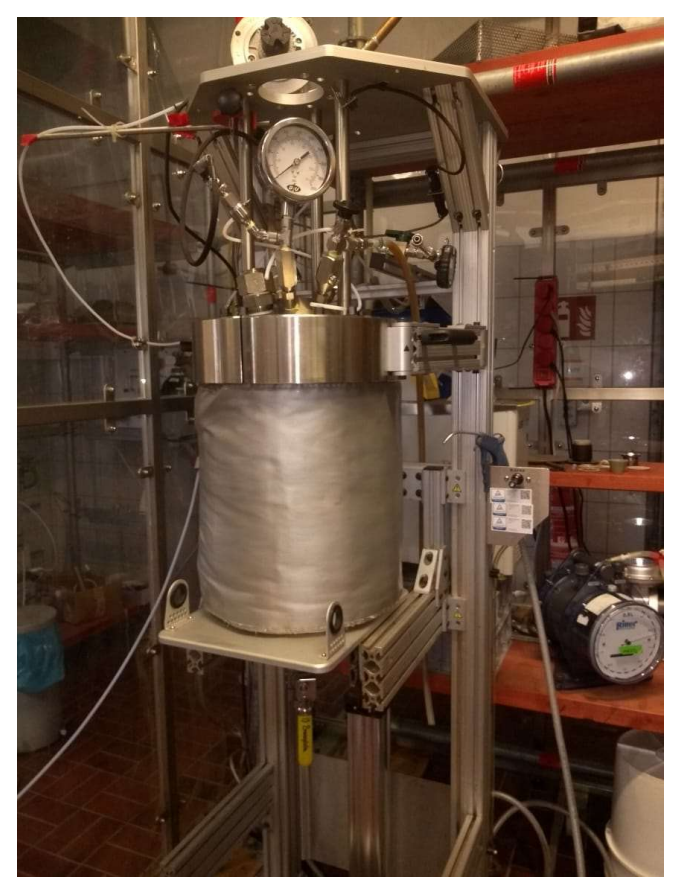

Figure 1. View of pilot scale stirred tank stainless steel reactor of 18.875 L (Parr, USA, Model: 4555).

\subsubsection{Experimental procedures}

The hydrothermal processing of dried Açaí (Euterpe Oleracea, Mart) seeds carried out with hot compressed at $175,200,225$, and $250{ }^{\circ} \mathrm{C}, 240$ minutes, biomass-to-water ratio of $1: 10$, and at $250{ }^{\circ} \mathrm{C}, 240$ minutes, and biomass-to-water ratios of 1:10, 1:15, and 1:20, as described in details elsewhere [14]. 


\subsection{Compositional analysis of reaction products}

\subsubsection{Aqueous phase}

The chemical analysis of volatile low-chain length carboxylic acids ( $\mathrm{R}-\mathrm{COOH}$, with $\left.\mathrm{R}_{1}=\mathrm{CH}_{3}, \mathrm{R}_{2}=\mathrm{C}_{2} \mathrm{H}_{5}, \mathrm{R}_{3}=\mathrm{C}_{3} \mathrm{H}_{7}, \mathrm{R}_{4}=\mathrm{C}_{4} \mathrm{H}_{9}\right)$ and alcohols (R-OH, with $\left.\mathrm{R}_{1}=\mathrm{CH}_{3}, \mathrm{R}_{2}=\mathrm{C}_{2} \mathrm{H}_{5}, \mathrm{R}_{3}=\mathrm{C}_{3} \mathrm{H}_{8}\right)$, selective cellulose/hemicellulose-derived compounds by hydrothermal processing of biomass, identified by GC while the selective cellulose/hemicellulose-derived phenolic (phenol, cresol, catechol, and guaiacol) and aldehydes (Furfural, HMF) compounds identified by HPLC. The equipment specifications (GC, HPLC) and operating conditions described in details elsewhere [14].

\subsubsection{Gaseous phase}

The volume of gas, degassed at $25^{\circ} \mathrm{C}$ and 1.0 atmosphere, measured with a gas flow meter, while an infrared gas analyzer was used to determine the volumetric composition of gaseous products [14]. The equipment's specifications and procedures described in details elsewhere [14].

\subsection{Steady state material balance by hydrothermal carbonization}

The yields of reaction products (solid, liquid, and gaseous phases) were determined by applying the mass conservation principle within the stirred tank reactor, operating in batch mode, closed thermodynamic system, and the equations described in details elsewhere [14].

\section{Results}

\subsection{Hydrothermal processing of Açaí seeds}

3.1.1. Material balances, operating conditions, and yields of reaction products:

The material balances, operating conditions, and yields of reaction products by hydrothermal processing of Açaí seeds in nature at $175,200,225,250{ }^{\circ} \mathrm{C}, 2{ }^{\circ} \mathrm{C} / \mathrm{min}, 240 \mathrm{~min}$, and biomass-to-water ratio of 1:10, are summarized in Table 1.

Table 1. Mass balances, process and operating conditions, and yields of solid, liquid, and gaseous products by hydrothermal processing of Açaí seeds with hot compressed $\mathrm{H}_{2} 0$ at 175, 200, 225, 250 ${ }^{\circ} \mathrm{C}, 2{ }^{\circ} \mathrm{C} / \mathrm{min}, 240 \mathrm{~min}$, and biomass-to-water ratio of 1:10.

\begin{tabular}{|c|c|c|c|c|}
\hline \multirow[b]{2}{*}{ Process Parameters } & \multicolumn{3}{|c|}{$\begin{array}{c}\text { Temperature } \\
{\left[{ }^{\circ} \mathrm{C}\right]} \\
\end{array}$} & \multirow[b]{2}{*}{250} \\
\hline & 175 & 200 & 225 & \\
\hline Mass of Açaí Seeds [g] & 300.00 & 299.82 & 299.98 & 300.16 \\
\hline Mass of $\mathrm{H}_{2} \mathrm{O}[\mathrm{g}]$ & 2997.60 & 3000.20 & 3001.30 & 2999.90 \\
\hline Mechanical Stirrer Speed [rpm] & 90 & 90 & 90 & 90 \\
\hline Initial Temperature $\left[{ }^{\circ} \mathrm{C}\right]$ & 30 & 30 & 30 & 30 \\
\hline Heating Rate $\left[{ }^{\circ} \mathrm{C} / \mathrm{min}\right]$ & 2 & 2 & 2 & 2 \\
\hline Process Time [min] & 240 & 240 & 240 & 240 \\
\hline Mass of Slurry [g] & 3252.20 & 3240.20 & 3216.50 & 3167.40 \\
\hline Volume of Gas $[\mathrm{mL}], \mathrm{T}=25^{\circ} \mathrm{C}, \mathrm{P}=1 \mathrm{~atm}$ & 0 & 5290 & 5590 & 7470 \\
\hline Mass of Gas [g] & 0 & 7.564 & 8.231 & 11.408 \\
\hline Process Loss (I) [g] & 45.40 & 59.82 & 84.78 & 132.66 \\
\hline Input Mass of Slurry (Pressing) [g] & 3252.20 & 3240.20 & 3216.50 & 3161.70 \\
\hline Process Loss (II) [g] & 0.00 & 0.00 & 0.00 & 5.70 \\
\hline Mass of Liquid Phase [g] & 2638.53 & 2615.56 & 2637.97 & 2556.96 \\
\hline Mass of Moist Hydro-char [g] & 588.10 & 587.37 & 557.61 & 591.29 \\
\hline Process Loss (III) [g] & 25.57 & 37.27 & 20.92 & 13.41 \\
\hline Mass of Dry Hydro-char [g] & 160.16 & 118.53 & 113.052 & 111.092 \\
\hline $\begin{array}{l}\text { (Mass of Liquid Phase }+\sum \text { Process Loss }+ \\
\text { Mass of Moist Hydro-char - Mass of Dry } \\
\text { Hydro-char - Mass of Gas) [g] }\end{array}$ & 3137.44 & 3173.926 & 3179.997 & 3177.52 \\
\hline Process Loss (I + II + III) [g] & 70.97 & 97.09 & 105.70 & 151.77 \\
\hline Mass of LiquidReaction [g] & 139.84 & 173.726 & 178.697 & 177.62 \\
\hline Yield of Hydro-char [wt.\%] & 53.39 & 39.534 & 37.686 & 37.011 \\
\hline Yield of Liquid Phase [wt.\%] & 46.61 & 57.943 & 59.570 & 59.188 \\
\hline Yield of Gas [wt.\%] & 0.000 & 2.523 & 2.744 & 3.801 \\
\hline
\end{tabular}


Figure 2 shows the effect of temperature on the yields of reaction products by hydrothermal processing of Açaí seeds in nature with hot compressed $\mathrm{H}_{2} \mathrm{O}$ at 175, 200, 225, 250 ${ }^{\circ} \mathrm{C}, 2{ }^{\circ} \mathrm{C} / \mathrm{min}, 240 \mathrm{~min}$, and biomass-to-water ratio of 1:10. The exponential function was applied to regress the yields of reaction products, correlating well the experimental data for both the solid and liquid phases, with $\mathrm{r}^{2}$ (R-Squared) between 0.996 and 0.996 . The yield of solids shows a smooth first-order exponential decay behavior, while that of liquid and gaseous phases a smooth first-order exponential growth. At $175^{\circ} \mathrm{C}$ hydrothermal carbonization takes places, as the main reaction product is a solid [15]. From $200{ }^{\circ} \mathrm{C}$, hydrothermal liquefaction occurs, as the maim reaction products are liquids [15]. The hydrochar yields are according to those reported in the literature for Rye straw [16], Eucalyptus leaves [17], corn Stover [14], Sugarcane bagasse [18]; and corn Stalk [19].

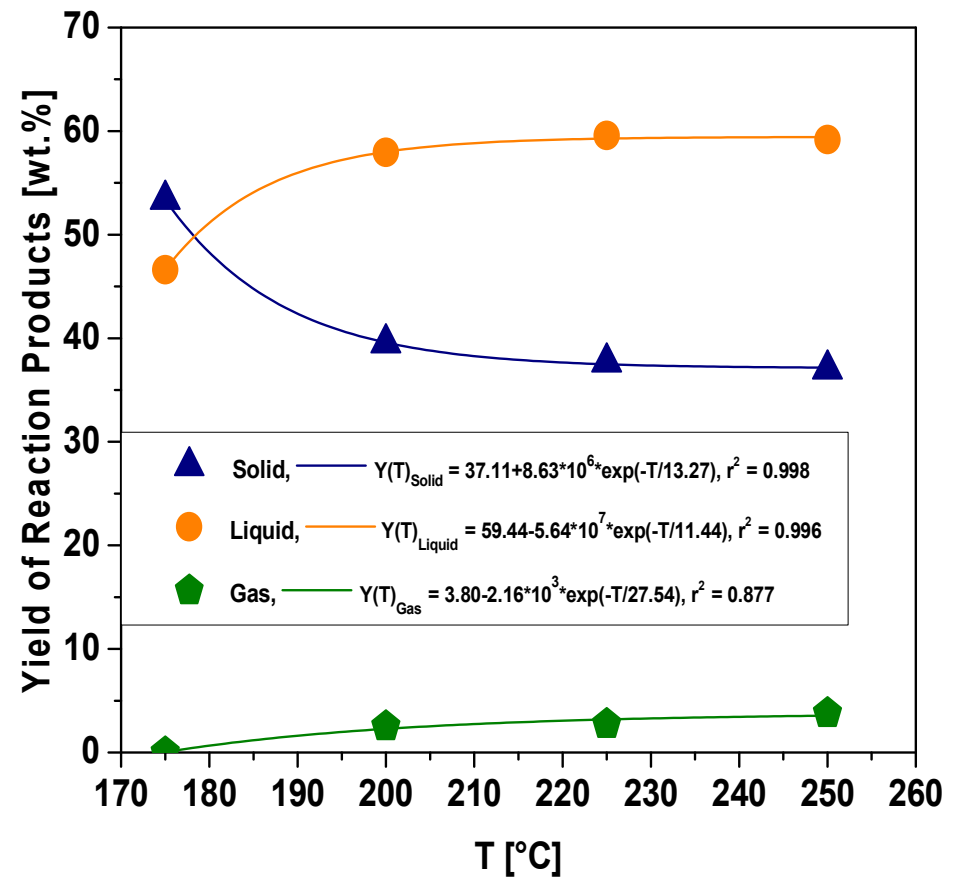

Figure 2. Effect of temperature on the yields of reaction products by hydrothermal processing of Açaí seeds in nature.

Based on the centesimal composition of Açaí (Euterpe oleracea Mart.) seeds [12], containing $40.29 \%$ (wt.) cellulose, 5.5\% (wt.) hemi-cellulose, $4.0 \%$ (wt.) lignin, $29.79 \%$ fibers, as well as $6.25 \%$ (wt.) proteins, $0.61 \%$ (wt.) lipids, $10.15 \%$ (wt.) moisture, $0.5 \%$ (wt.) volatile matter, $0.83 \%$ (wt.) fixed carbon, and $0.15 \%$ (wt.) ash (Supplementary Table TS1), and on the composition of Açaí fibers in nature, containing $41.37 \%$ (wt.) cellulose, $11.54 \%$ (wt.) hemi-cellulose, $40.25 \%$ (wt.) lignin, $1.96 \%$ ash, and $8.88 \%$ moisture, as reported by Tavares et. all. [7], that $61.25 \%$ (wt.) cellulose and 15\% (wt.) lignin decompose by $200{ }^{\circ} \mathrm{C}, 24$ hours, 1:10 biomass-to-water ratio, according to Falco et. all. [16], that 5.0\% (wt.) lipids and 72\% (wt.) proteins decompose at $350{ }^{\circ} \mathrm{C}, 90 \mathrm{~min}, 1: 5.7$ biomass-to-water ratio, as reported by Teri et. all. [20], that hemicellulose degrades 65\% (wt.) by severity factor between 4.5 and 5.0, as reported by Borrero-López et. all. [21], and that approximately 50\% (wt.) cotton fibers decompose at $210^{\circ} \mathrm{C}, 8.0$ hours, 1:41 biomass-to-water ratio, as reported by Zhang et. all. [22], one may perform a centesimal mass balance to compute the approximate theoretical mass degradation of Açaí seeds at $200{ }^{\circ} \mathrm{C}, 2{ }^{\circ} \mathrm{C} / \mathrm{min}, 240 \mathrm{~min}$, and biomass-to-water ratio 
of 1:10, using the simple equation as follows $\mathrm{Y}_{\text {solid }}=\Sigma$ $\{40.29 \% \text { (wt. })^{*} 0.3875+4.0 \%$ (wt. $)^{*} 0.85+5.5 \%$ (wt. $)^{*} 0.35+6.25 \%$ (wt. $)^{*} 0.28+0.61 \%($ wt. $) * 0.95+[29$. $79 \%$ (wt. $)^{*} 0.4137^{*} 0.3875+29.79 \%(\text { wt. })^{*} 0.1154^{*} 0.35+29.79 \%(\text { wt. })^{*} 0.4025^{*} 0.85+29.79 \% * 0.0199($ wt.) Ash $]+\sum[0.83 \%(w t$.$) Fixed Carbon +0.15 \%$ (wt.)Ash $\}=41.01 \%$ (wt.), very close to the experimental value of $39.534 \%$ (wt.), showing a deviation of $3.73 \%$. In addition, the computed amount of Açaí seeds fibers [29.79\% (wt.)] degraded at $200{ }^{\circ} \mathrm{C}, 240 \mathrm{~min}$, and biomass-towater ratio of $1: 10$ was $13.03 \%$ (wt.), giving a degradation percentual of $43.74 \%$, very close to the results reported by Zhang et. all. [22], who stated that approximately $50 \%$ (wt.) cotton fibers decompose at $210{ }^{\circ} \mathrm{C}, 8.0$ hours, $1: 41$ biomass-to-water ratio.

By analyzing the thermal decomposition behavior of cellulose and lignin reported by Falco et. all. [16], one observes that decomposition of cellulose is almost constant between $200{ }^{\circ} \mathrm{C}$ and $240^{\circ} \mathrm{C}(38.75 \rightarrow 37.00)$, showing that degradation/depolymerization of cellulose is less intense [19], while lignin loses only $7.5 \%$ its initial mass $(85 \% \rightarrow 77.5 \%)$, thus making it possible to explain the small differences for the solid phase yields between $200{ }^{\circ} \mathrm{C}$ and $250{ }^{\circ} \mathrm{C}$.

Table 2 describes in details the material balances, operating conditions, and yields of reaction products by hydrothermal processing of Açaí seeds in nature at $250{ }^{\circ} \mathrm{C}, 2^{\circ} \mathrm{C} / \mathrm{min}$, $240 \mathrm{~min}$, and biomass-to-water ratios of 1:10, 1:15, and 1:20.

Table 2. Mass balances, process and operating conditions, and yields of solid, liquid, and gaseous phases by hydrothermal processing of Açaí seeds with hot compressed $\mathrm{H}_{2} 0$ at $250{ }^{\circ} \mathrm{C}, 2{ }^{\circ} \mathrm{C} / \mathrm{min}, 240$ min, and biomass-to-water ratios of 1:10, 1:15, and 1:20.

\begin{tabular}{lccc}
\hline & \multicolumn{3}{c}{$\mathbf{2 5 0}{ }^{\circ} \mathrm{C}$} \\
\cline { 2 - 3 } \multicolumn{1}{c}{ Process Parameters } & $\mathbf{1 : 1 0}$ & $\mathbf{1 : 1 5}$ & $\mathbf{1 : 2 0}$ \\
\hline Mass of Açaí Seeds [g] & $\mathbf{3 0 0 . 1 6}$ & $\mathbf{3 0 0 . 2 8}$ & $\mathbf{3 0 0 . 0 7}$ \\
Mass of $\mathrm{H}_{2} \mathrm{O}$ [g] & $\mathbf{2 9 9 9 . 9 0}$ & $\mathbf{4 5 0 2 . 9 0}$ & $\mathbf{6 0 0 0 . 8 0}$ \\
Mechanical Stirrer Speed [rpm] & 90 & 90 & 90 \\
Initial Temperature [ ${ }^{\circ} \mathrm{C}$ ] & 30 & 30 & 30 \\
Heating Rate [ ${ }^{\circ} \mathrm{C} / \mathrm{min}$ ] & 2 & 2 & 2 \\
Process Time [min] & 240 & 240 & 240 \\
Mass of Slurry [g] & $\mathbf{3 1 6 7 . 4 0}$ & $\mathbf{4 6 9 6 . 5 0}$ & $\mathbf{6 2 1 7 . 4 0}$ \\
Volume of Gas [mL], T = 25 ${ }^{\circ} \mathrm{C}, \mathrm{P}=1$ atm & $\mathbf{7 4 7 0}$ & $\mathbf{1 2 4 0}$ & $\mathbf{1 2 2 5}$ \\
Mass of Gas [g] & $\mathbf{1 1 . 4 0 8}$ & $\mathbf{1 . 9 0 5}$ & $\mathbf{1 . 8 6 3}$ \\
Process Loss (I) [g] & $\mathbf{1 3 2 . 6 6}$ & $\mathbf{1 0 6 . 6 8}$ & $\mathbf{8 3 . 4 7}$ \\
Input Mass of Slurry (Pressing) [g] & 3161.70 & 4696.50 & 6209.30 \\
Process Loss (II) [g] & $\mathbf{5 . 7 0}$ & $\mathbf{0 . 0 0}$ & $\mathbf{8 . 1 0}$ \\
Mass of Liquid Phase [g] & 2556.96 & 4077.05 & 5663.60 \\
Mass of Moist Hydro-char [g] & 591.29 & 585.83 & 518.45 \\
Process Loss (III) [g] & $\mathbf{1 3 . 4 1}$ & $\mathbf{3 3 . 6 2}$ & $\mathbf{3 5 . 3 5}$ \\
Mass of Dry Hydro-char [g] & $\mathbf{1 1 1 . 0 9 2}$ & $\mathbf{1 0 2 . 2 5}$ & $\mathbf{9 6 . 3 0 2}$ \\
(Mass of Liquid Phase + $\Sigma$ Process Loss + & & & \\
Mass of Moist Hydro-char - Mass of Dry & 3177.52 & 5000.795 & 6210.805 \\
Hydro-char - Mass of Gas) [g] & & & \\
Process Loss (I + II + III) [g] & $\mathbf{1 5 1 . 7 7}$ & $\mathbf{1 4 0 . 3 0}$ & $\mathbf{1 2 6 . 9 2}$ \\
Mass of LiquidReaction [g] & 177.62 & 196.125 & 202.535 \\
Yield of Hydro-char [wt.\%] & $\mathbf{3 7 . 0 1 1}$ & $\mathbf{3 4 . 0 5 1}$ & $\mathbf{3 2 . 0 9 3}$ \\
Yield of Liquid Phase [wt. \%] & $\mathbf{5 9 . 1 8 8}$ & $\mathbf{6 5 . 3 1 5}$ & $\mathbf{6 7 . 2 8 6}$ \\
Yield of Gas [wt.\%] & $\mathbf{3 . 8 0 1}$ & $\mathbf{0 . 6 3 4}$ & $\mathbf{0 . 6 2 1}$ \\
\hline
\end{tabular}

The effect of $\mathrm{H}_{2} 0$-to-Biomass ratio on the yields of reaction products (solid, liquid, and gas) by hydrothermal of Açaí seeds in nature, illustrated in Figure 3 (a) and comparison of hydro-char yields with similar data reported in the literature, shown in Figure 3 (b). At $250{ }^{\circ} \mathrm{C}$ hydrothermal liquefaction is dominant, as the main reaction products formed are liquids [15]. The yields of reaction products, illustrated in Figure 3 (a), were regressed using a dose-response function, showing $\mathrm{r}^{2}$ (R-Squared) between 0.97 and 0.99 . The yields of hydro-char and gas decrease with $\mathrm{H}_{2} 0$-to-water ratios, while that of liquid phase increases. By increasing the $\mathrm{H}_{2} \mathrm{O}$-to-Biomass ratio, the amount of reaction media (hot 
compressed $\mathrm{H}_{2} 0$ ) increases, increasing the number of hydroxonium ion $\left(\mathrm{H}_{3} \mathrm{O}^{+}\right)$and a hydroxide ion $(\mathrm{OH})$ dissociated within the reaction system, thus improving the catalyzes of chemical reactions such as hydrolysis and organic compounds degradation (e.g. depolymerization, fragmentation) without aid a catalyst [23]. In fact, according to the literature [24-25], increasing the $\mathrm{H}_{2} 0$-to-Biomass ratio causes a great impact on hydrolysis reactions by hydrothermal processing of biomass.

A compilation of similar data on the effect of $\mathrm{H}_{2} 0$-to-Biomass ratio over hydro-char yields illustrated in Figure $3(\mathrm{~b})$. The behavior of hydro-char yields is similar, showing a decrease on the hydro-char yields as the $\mathrm{H}_{2} 0$-to-Biomass ratio increases. The data for $A c ̧ a i ́$ seeds, tomato-pell-waste [26], olive stone [27], and corn Stalk [19], were regressed using a doseresponse function, showing $\mathrm{r}^{2}$ (R-Squared) between 0.941 and 0.969 .

The experimental data are not only according to similar data reported in the literature for tomato-pell-waste [26], olive stone [27], microalgae [28], sawdust [29]; banana peels [30], wood ships [25], but close to that of corn Stalk [19], carried out at $250{ }^{\circ} \mathrm{C}$ and $4.0 \mathrm{~h}$.

By analyzing Figure 3 (b), one observes that temperature has a combined effect on the hydro-char yield with varying $\mathrm{H}_{2} 0$-to-Biomass ratios. At higher temperatures $\left(250^{\circ} \mathrm{C}\right)$, the effect of $\mathrm{H}_{2} 0$-to-Biomass is more intense, playing an important role on hydro-char yield. For low-medium hydrothermal processing temperatures, the effect of $\mathrm{H}_{2} 0$-to-Biomass on hydro-char yield is secondary, as reported by [26].

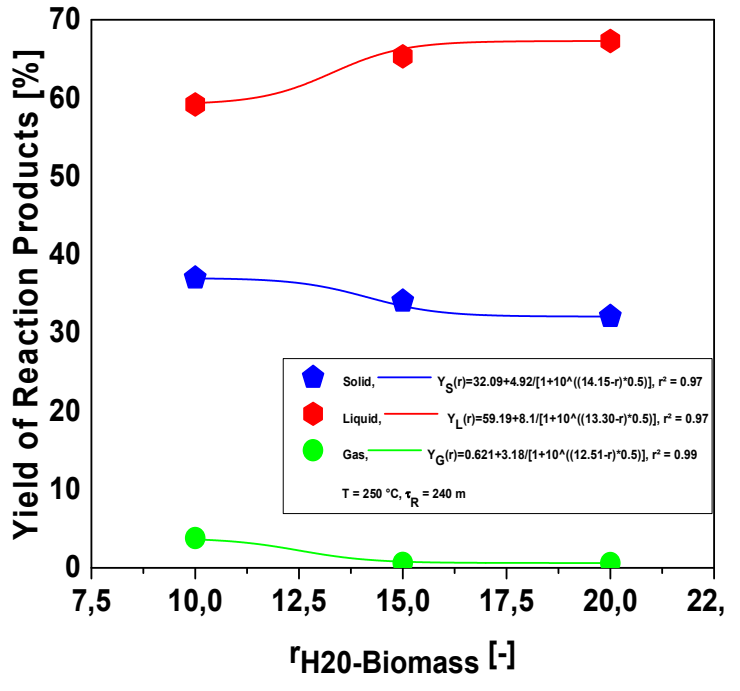

(a)

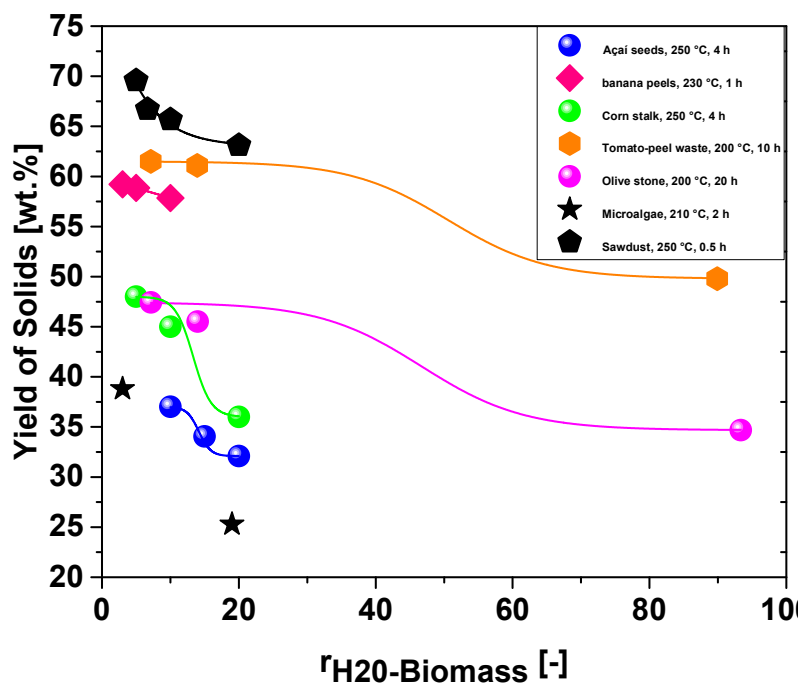

(b)

Figure 3. Effect of $\mathrm{H}_{2} 0$-to-Biomass ratio on the yields of reaction products (solid, liquid, gas) (a) and comparison of hydrochar yields with similar data reported in the literature (b).

\subsubsection{Chemical composition of gas reaction products}

The volume of gas degassed at $25^{\circ} \mathrm{C}$ and 1.0 atmosphere by hydrothermal processing of Açaí seeds with hot compressed $\mathrm{H}_{2} 0$ at $175,200,225,250^{\circ} \mathrm{C}, 2{ }^{\circ} \mathrm{C} / \mathrm{min}, 240 \mathrm{~min}$, and biomass-to-water ratio of 1:10 is shown in Figure 4 (a) and the volumetric composition of gaseous products in Figure 4 (b). The volume of gas increases exponentially as the process temperature increases and the same behavior was reported for the hydrothermal carbonization of corn Stover by Machado et. all. [14]. Similar studies reported that volume of gaseous products increases with temperature [18, 31-32]. 


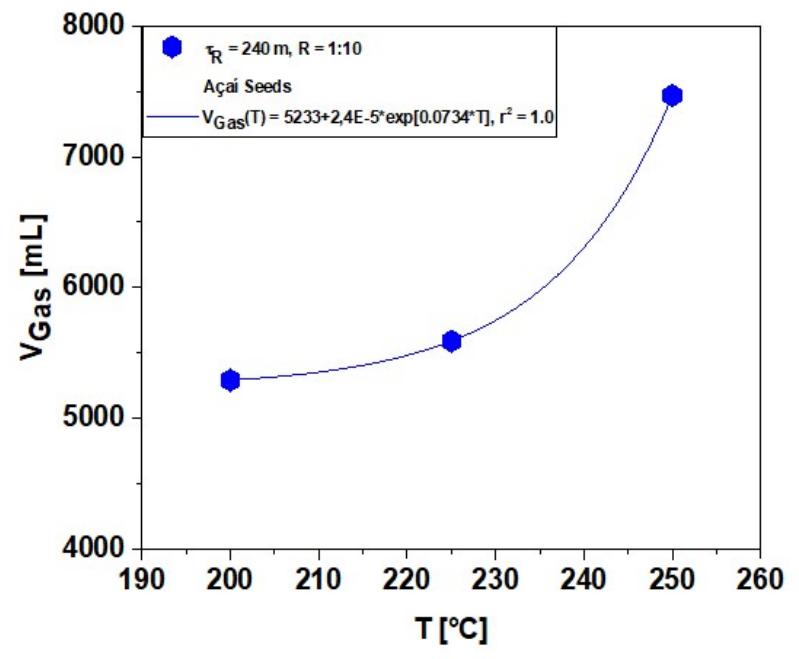

(a)

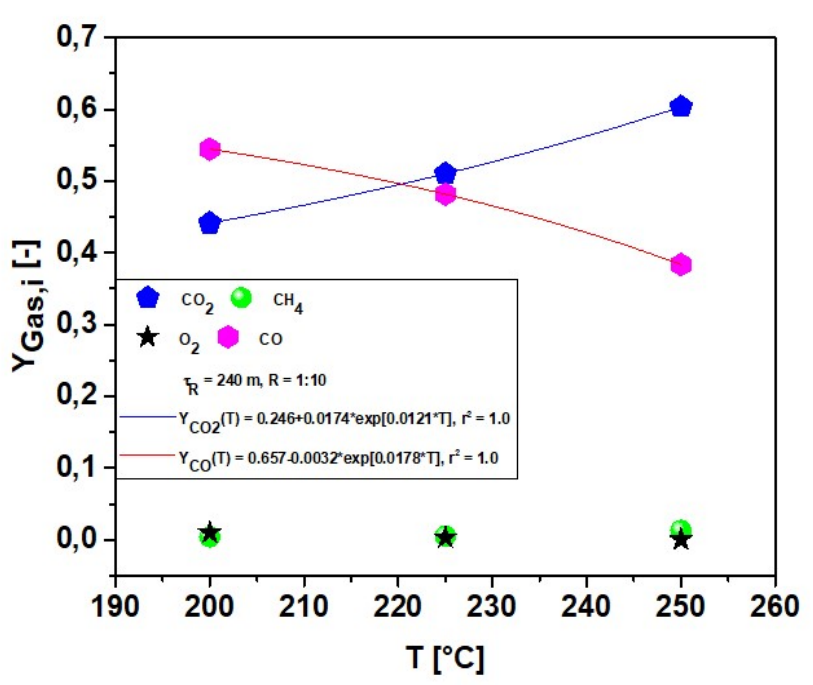

(b)

Figure 4. Effect of process temperature on the volume of gas degassed at $25^{\circ} \mathrm{C}$ and 1.0 atmosphere (a) and on the chemical composition of gas reaction products, expressed in mole fraction (b).

Table 3. Volume of gas and composition of gas products at $25^{\circ} \mathrm{C}$ and 1.0 atmosphere by hydrothermal processing of Açaí seeds with hot compressed $\mathrm{H}_{2} \mathrm{O}$ at $175,200,225,250{ }^{\circ} \mathrm{C}, 2{ }^{\circ} \mathrm{C} / \mathrm{min}, 240 \mathrm{~min}$, and biomass-to-water ratio of 1:10.

\begin{tabular}{|c|c|c|c|c|}
\hline \multirow[b]{2}{*}{ Composition [vol.\%] } & \multicolumn{4}{|c|}{$\begin{array}{c}\text { Temperature } \\
{\left[{ }^{\circ} \mathrm{C}\right]}\end{array}$} \\
\hline & 175 & 200 & 200 & 200 \\
\hline$\overline{\mathrm{CO}_{2} \text { [vol.\%] }}$ & 0.00 & 44.40 & 51.30 & 60.60 \\
\hline $\mathrm{CH}_{4}[\mathrm{vol} . \%]$ & 0.00 & 0.40 & 0.50 & 1.30 \\
\hline $\mathrm{O}_{2}$ [vol. \%] & 0.00 & 1.0 & 0.30 & 0.00 \\
\hline $100-\Sigma\left(\mathrm{CO}_{2}+\mathrm{CH}_{4}+\mathrm{O}_{2}\right)[$ vol. $\%]$ & 0.00 & 54.20 & 47.90 & 38.10 \\
\hline Volume of Gas [mL] & 0.00 & 5290 & 5590 & 7470 \\
\hline Volume of $\mathrm{CO}_{2}[\mathrm{~mL}]$ & 0.00 & 2348.76 & 2867.67 & 4526.82 \\
\hline Volume of $\mathrm{CH}_{4}[\mathrm{~mL}]$ & 0.00 & 21.16 & 27.95 & 97.11 \\
\hline Volume of $\mathrm{O}_{2}[\mathrm{~mL}]$ & 0.00 & 52.90 & 16.77 & 0.00 \\
\hline 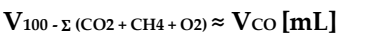 & 0.00 & 2867.18 & 2677.61 & 2846.07 \\
\hline Mass of Gas[g] & 0.00 & 7.564 & 8.231 & 11.408 \\
\hline Mass of $\mathrm{CO}_{2}[\mathrm{~g}]$ & 0.00 & 4.191 & 5.117 & 8.078 \\
\hline Mass of $\mathrm{CH}_{4}[\mathrm{~g}]$ & 0.00 & 0.014 & 0.018 & 0.063 \\
\hline Mass of $\mathrm{O}_{2}[\mathrm{~g}]$ & 0.00 & 0.068 & 0.022 & 0.000 \\
\hline Mass of $\mathrm{CO}[\mathrm{g}]$ & 0.00 & 3.291 & 3.074 & 3.267 \\
\hline \multicolumn{5}{|l|}{ Composition of Gas [mol.\%] } \\
\hline $\mathrm{Y}^{\mathrm{CO} 2} \mathrm{~T}$ & 0.00 & 0.441410 & 0.510306 & 0.603507 \\
\hline $\mathrm{YCH}^{\mathrm{CH}}$ & 0.00 & 0.004055 & 0.004936 & 0.012943 \\
\hline $\mathrm{YO}^{\mathrm{O} 2}$ & 0.00 & 0.009848 & 0.003017 & 0.000000 \\
\hline $\mathrm{Y}^{100-\Sigma(\mathrm{CO}+\mathrm{CH} 4+\mathrm{O} 2) \approx} \mathrm{YCO}^{\mathrm{CO}}$ & 0.00 & 0.544687 & 0.481741 & 0.383550 \\
\hline
\end{tabular}

The infrared gas analyzer identified the presence of $\mathrm{CO}_{2}, \mathrm{O}_{2}, \mathrm{CH}_{4}$, and $\mathrm{CO}$ was computed by difference [14], as summarized in Tables 3 and 4, being $\mathrm{CO}_{2}$, the most abundant gaseous specie produced. This is according to similar studies on the evaluation of gaseous products and compositions by hydrothermal processing of biomass [14, 18, 31, 33-34]. The presence of high volumetric concentrations of $\mathrm{CO}_{2}$ in the gaseous phase indicates that decarboxylation is probably one of the dominant reaction mechanisms/pathways by hydrothermal processing of Açaí seeds in nature, being according to Li et. all. [35]. In fact, according to the literature [36], by hydrothermal processing of biomass, decarboxylation 
takes place, yielding $\mathrm{CO}_{2}$, but other sources can also produce $\mathrm{CO}_{2}$, including de decomposition of $\mathrm{HCOOH}$, produced during the hydrothermal degradation of cellulose, and until condensation reactions.

The effect of temperature on the chemical composition of gas reaction products is shown in Figure 4 (b). The mole fraction of $\mathrm{CO}$ shows a smooth exponential decay behavior and the mole fraction of $\mathrm{CO}_{2}$ a smooth exponential growth. An increase on $\mathrm{CO}_{2}$ concentration in the gaseous phase by hydrothermal processing of biomass may be explained by analogy to the mild torrefaction process of biomass, as reported by Wannapeera et. all. [37]. By increasing the process temperature, the oxygen functional groups in the Açaí seeds are decomposed resulting not only in higher amounts of gas formed, but also in higher yields of $\mathrm{CO}_{2}$.

Table 3. Volume of gas and composition of gas products at $25^{\circ} \mathrm{C}$ and 1.0 atmosphere by hydrothermal processing of Açaí seeds with hot compressed $\mathrm{H}_{2} 0$ at $175,200,225,250{ }^{\circ} \mathrm{C}, 2{ }^{\circ} \mathrm{C} / \mathrm{min}, 240 \mathrm{~min}$, and biomass-to-water ratio of 1:10.

\begin{tabular}{|c|c|c|c|c|}
\hline \multirow[b]{2}{*}{ Composition [vol.\%] } & \multicolumn{4}{|c|}{$\begin{array}{c}\text { Temperature } \\
{\left[{ }^{\circ} \mathrm{C}\right]} \\
\end{array}$} \\
\hline & 175 & 200 & 200 & 200 \\
\hline $\mathrm{CO}_{2}$ [vol.\%] & 0.00 & 44.40 & 51.30 & 60.60 \\
\hline $\mathrm{CH}_{4}$ [vol.\%] & 0.00 & 0.40 & 0.50 & 1.30 \\
\hline $\mathrm{O}_{2}[\mathrm{vol} . \%]$ & 0.00 & 1.0 & 0.30 & 0.00 \\
\hline $100-\Sigma\left(\mathrm{CO}_{2}+\mathrm{CH}_{4}+\mathrm{O}_{2}\right)[\mathrm{vol} . \%]$ & 0.00 & 54.20 & 47.90 & 38.10 \\
\hline Volume of Gas [mL] & 0.00 & 5290 & 5590 & 7470 \\
\hline Volume of $\mathrm{CO}_{2}[\mathrm{~mL}]$ & 0.00 & 2348.76 & 2867.67 & 4526.82 \\
\hline Volume of $\mathrm{CH}_{4}[\mathrm{~mL}]$ & 0.00 & 21.16 & 27.95 & 97.11 \\
\hline Volume of $\mathrm{O}_{2}[\mathrm{~mL}]$ & 0.00 & 52.90 & 16.77 & 0.00 \\
\hline $\mathrm{V}_{100-\Sigma}\left(\mathrm{CO}_{2}+\mathrm{CH} 4+\mathrm{O} 2\right) \approx \mathrm{V}_{\mathrm{CO}}[\mathrm{mL}]$ & 0.00 & 2867.18 & 2677.61 & 2846.07 \\
\hline Mass of Gas[g] & 0.00 & 7.564 & 8.231 & 11.408 \\
\hline Mass of $\mathrm{CO}_{2}[\mathrm{~g}]$ & 0.00 & 4.191 & 5.117 & 8.078 \\
\hline Mass of $\mathrm{CH}_{4}[\mathrm{~g}]$ & 0.00 & 0.014 & 0.018 & 0.063 \\
\hline Mass of $\mathrm{O}_{2}[\mathrm{~g}]$ & 0.00 & 0.068 & 0.022 & 0.000 \\
\hline Mass of $\mathrm{CO}[\mathrm{g}]$ & 0.00 & 3.291 & 3.074 & 3.267 \\
\hline \multicolumn{5}{|l|}{ Composition of Gas [mol.\%] } \\
\hline $\mathrm{YCO}^{2}$ & 0.00 & 0.441410 & 0.510306 & 0.603507 \\
\hline $\mathrm{YCH}^{\mathrm{CH}}$ & 0.00 & 0.004055 & 0.004936 & 0.012943 \\
\hline $\mathrm{Y}^{\mathrm{O} 2}$ & 0.00 & 0.009848 & 0.003017 & 0.000000 \\
\hline $\mathrm{Y}^{100-\Sigma(\mathrm{CO} 2+\mathrm{CH} 4+\mathrm{O} 2) \approx} \mathrm{YCO}$ & 0.00 & 0.544687 & 0.481741 & 0.383550 \\
\hline
\end{tabular}

The effect of $\mathrm{H}_{2} 0$-to-Biomass ratio on the volume of gas degassed at $25{ }^{\circ} \mathrm{C}$ and 1.0 atmosphere by hydrothermal of Açaí seeds in nature with hot compressed $\mathrm{H}_{2} \mathrm{O}$ at $250{ }^{\circ} \mathrm{C}$, $2{ }^{\circ} \mathrm{C} / \mathrm{min}, 240 \mathrm{~min}$, and biomass-to-water ratios of 1:10, 1:15, and 1:20, illustrated in Figure 5. By increasing the $\mathrm{H}_{2} 0$-to-Biomass ratio, the volume of gas depletes, indicating that hydrolysis may be the dominant reaction mechanism [24; 38].

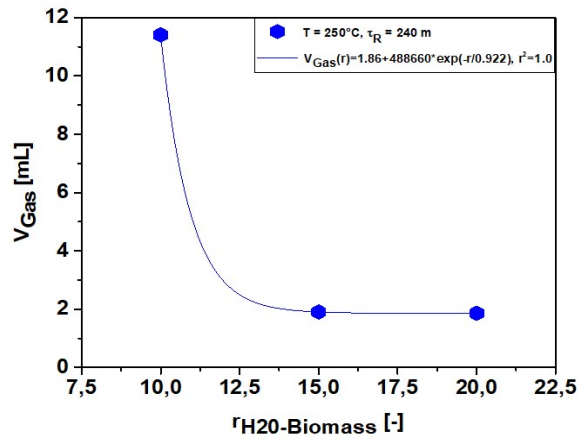

Figure 5. Effect of H20-to-Biomass on the volume of gas degassed at $25^{\circ} \mathrm{C}$ and 1.0 atmosphere by hydrothermal processing of Açaí seeds with hot compressed $\mathrm{H}_{2} 0$. 
Table 4. Volume of gas and composition of gas products at $25^{\circ} \mathrm{C}$ and 1.0 atmosphere as a function of temperature by hydrothermal processing of Açaí seeds with hot compressed $\mathrm{H}_{2} \mathrm{O}$ at $250{ }^{\circ} \mathrm{C}, 2$ ${ }^{\circ} \mathrm{C} / \mathrm{min}, 240 \mathrm{~min}$, and biomass-to-water ratios of 1:10, 1:15, and 1:20.

\begin{tabular}{|c|c|c|c|}
\hline \multirow[b]{2}{*}{ Composition [vol.\%] } & \multirow[b]{2}{*}{ 1:10 } & \multicolumn{2}{|c|}{$\begin{array}{c}250^{\circ} \mathrm{C} \\
\text { Biomass/ } \mathrm{H}_{2} \mathrm{O}[-\end{array}$} \\
\hline & & 1:15 & $1: 20$ \\
\hline$\overline{\mathrm{CO}_{2} \text { [vol.\%] }}$ & 60.60 & 63.40 & 59.90 \\
\hline $\mathrm{CH}_{4}[\mathrm{vol} . \%]$ & 1.30 & 3.10 & 1.60 \\
\hline $\mathrm{O}_{2}[\mathrm{vol} . \%]$ & 0.00 & 0.00 & 0.00 \\
\hline$\Sigma\left(\mathrm{CO}_{2}+\mathrm{CH}_{4}+\mathrm{O}_{2}\right)$ & 61.90 & 65.50 & 61.50 \\
\hline $100-\Sigma\left(\mathrm{CO}_{2}+\mathrm{CH}_{4}+\mathrm{O}_{2}\right)[\mathrm{vol} . \%]$ & 38.10 & 33.50 & 38.50 \\
\hline \multicolumn{4}{|l|}{ Volume of Gas [mL] } \\
\hline Volume of $\mathrm{CO}_{2}[\mathrm{~mL}]$ & 4526.82 & 786.16 & 733.775 \\
\hline Volume of $\mathrm{CH}_{4}[\mathrm{~mL}]$ & 97.11 & 38.44 & 19.60 \\
\hline Volume of $\mathrm{O}_{2}[\mathrm{~mL}]$ & 0.00 & 00.00 & 00.00 \\
\hline 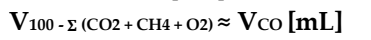 & 2846.07 & 415.40 & 471.625 \\
\hline \multicolumn{4}{|l|}{ Mass of Gas[g] } \\
\hline Mass of $\mathrm{CO}_{2}[\mathrm{~g}]$ & 8.078 & 1.403 & 1.309 \\
\hline Mass of $\mathrm{CH}_{4}[\mathrm{~g}]$ & 0.0629 & 0.0249 & 0.0127 \\
\hline Mass of $\mathrm{O}_{2}[\mathrm{~g}]$ & 0,00 & 0.00 & 0.00 \\
\hline Mass of $\mathrm{CO}[\mathrm{g}]$ & 3.267 & 0.477 & 0.541 \\
\hline \multicolumn{4}{|l|}{ Composition of Gas [mol.\%] } \\
\hline $\mathrm{YCO}^{\mathrm{CO}}$ & 0.6035 & 0.6317 & 0.5966 \\
\hline $\mathrm{YCH}^{\mathrm{CH}}$ & 0.0130 & 0.0308 & 0.0159 \\
\hline $\mathrm{Y}^{\mathrm{O} 2}$ & 0.000 & 0.000 & 0.000 \\
\hline $\mathrm{Y}^{100-\Sigma(\mathrm{CO} 2+\mathrm{CH} 4+\mathrm{O} 2) \approx} \approx \mathrm{YCO}$ & 0.3835 & 0.3375 & 0.3875 \\
\hline
\end{tabular}

3.1.1.2. Chemical composition of organic compounds in the aqueous phase

The effect of temperature on the concentration profile of aromatic-ring compounds (Furfural, HMF, Phenols, and Cathecol) and carboxylic acids $\left(\mathrm{CH}_{3} \mathrm{COOH}\right.$, $\mathrm{CH}_{3} \mathrm{CH}_{2} \mathrm{COOH}$ ) by hydrothermal processing of Açaí seeds, illustrated in Figure 6 (a) and (b), and the data summarized in Table 5.

Table 5. Concentration of aromatics compounds (HMF, furfural, phenol, cathecol), carboxylic acids $\left(\mathrm{CH}_{3} \mathrm{COOH}, \mathrm{CH}_{3} \mathrm{CH}_{2} \mathrm{COOH}\right)$ and total carboxylic acids (HAc) in aqueous phase at $25{ }^{\circ} \mathrm{C}$ and 1.0 atmosphere by hydrothermal processing of Açaí seeds with hot compressed $\mathrm{H}_{2} 0$ at 175, 200, 225, 250 ${ }^{\circ} \mathrm{C}, 2{ }^{\circ} \mathrm{C} / \mathrm{min}, 240 \mathrm{~min}$, and biomass-to-water ratio of 1:10.

\begin{tabular}{lcccc}
\hline & \multicolumn{5}{c}{ Temperature } \\
& \multicolumn{3}{c}{ [ ${ }^{\circ}$ C] } \\
\hline Concentration of aromatics [mg/L] & $\mathbf{1 7 5}$ & $\mathbf{2 0 0}$ & $\mathbf{2 2 5}$ & $\mathbf{2 5 0}$ \\
HMF: CAS: 67-47-0 & 492.3 & 474.8 & 170.1 & 24.45 \\
Furfural: CAS:98-01-1 & 227.80 & 119.50 & 96.83 & 5.05 \\
Phenol: CAS: 108-95-2 & 11.34 & - & 60.81 & 81.24 \\
Catechol: CAS: 120-80-9 & 63.86 & - & - & 193.8 \\
Concentration of carboxylic acids [mg/L] & & & & \\
Acetic acid: CAS: 64-19-7 & 700 & 1280 & 1410 & 1680 \\
Total acetic acid (HAc) & 773.2 & 1394 & 1540 & 1859 \\
Propionic Acid: CAS: 79-09-4 & 90 & 140 & 160 & 220 \\
Concentration of alcohols [mg/L] & & & & \\
Methanol: CAS: $67-56-1$ & $<20$ & $<20$ & $<20$ & $<20$ \\
Ethanol CAS: $64-17-5$ & $<20$ & $<20$ & $<20$ & $<20$ \\
Propanol CAS: 71-23-8 & $<20$ & $<20$ & $<20$ & $<20$ \\
Butanol CAS: 71-36-3 & $<20$ & $<20$ & $<20$ & $<20$ \\
\hline
\end{tabular}

By increasing the process temperature, the concentrations of furfural and HMF, by products of cellulose degradation, decreases exponentially, being present at very low concentrations at $250^{\circ} \mathrm{C}$, while the concentrations of phenols and cathecol, products of furfural and HMF degradation, increase, as shown in Figure 5 (a). 
By hydrothermal processing of biomass, as cellulose hydrolyzes, it forms glucose, being transformed by isomerization reactions into fructose [38]. The decomposition of monosaccharides (glucose, fructose) produces volatile carboxylic acids, dissociating within the reaction media, thus producing hydroxonium ion $\left(\mathrm{H}_{3} \mathrm{O}^{+}\right)$and increasing the ionic product of reacting media, improving the degradation of biomass [38]. The monosaccharides (glucose, fructose) also undergo dehydration and fragmentation reaction producing furfural-derived compounds (furfural, HMF), as well as acids and aldehydes [38]. Finally, as temperature increases, furfural-derived compounds (furfural, HMF) suffer degradation, producing acids, aldehydes, and phenols [38]. In this context, based on the reaction mechanism described by Sevilla and Fuertes [38], it is expected that, by increasing the process temperature, the concentrations of Furfural and HMF will decrease, while those of cathecol and phenols increase. The results are according to similar studies reported in the literature [14, 18, 39-41]. Jung et. all. [42], studied the growth mechanism of hydro-char and the kinetic model of fructose degradation by hydrothermal carbonization, concluding that HMF degrades forming hydro-char and $\mathrm{H}_{2} \mathrm{O}\left(\mathrm{HMF} \rightarrow \mathrm{Hydro}-\mathrm{char}+\mathrm{H}_{2} 0\right)$, following a first-order kinetics $\frac{d[\text { Hydro-char }]}{d t}=K *[H M F]$. This is according to the results for hydro-char yields in Table 1, that is, the higher the concentration of HMF, the higher the yield of hydro-char.

Figure 6 (b) shows that temperature has a great effect on concentrations of carboxylic acids $\left(\mathrm{CH}_{3} \mathrm{COOH}, \mathrm{CH}_{3} \mathrm{CH}_{2} \mathrm{COOH}\right)$ and total carboxylic acids (HAc) by hydrothermal processing of Açaí seeds with hot compressed $\mathrm{H}_{2} 0$ at $175,200,225,250{ }^{\circ} \mathrm{C}, 2{ }^{\circ} \mathrm{C} / \mathrm{min}, 240 \mathrm{~min}$, and biomass-to-water ratio of 1:10. The concentrations of carboxylic acids, particularly $\mathrm{CH}_{3} \mathrm{COOH}$, the most predominant one, as well as the concentration total carboxylic acids (HAc), increase strongly with temperature. By hydrothermal processing of biomass, the monosaccharides (glucose, fructose) produced by hydrolysis of biomass are decomposed forming volatile carboxylic acids, including acetic and propionic acids [38]. As reported by Hoekman et. all. [18, 43], and Machado et. all. [14], the concentrations of acetic acid and total organic acids produced by hydrothermal processing of different biomass feedstocks increases with temperature. Poerschmann et. all. [44], investigated the distribution of main medium molar mass compounds dissolved in process water by hydrothermal carbonization of glucose, fructose and xylose at 180,220 , and $250{ }^{\circ} \mathrm{C}$ by GC-MS and IC, reporting acetic acid concentrations of 4560 and 3920 for degradation of glucose and fructose, respectively, at $220^{\circ} \mathrm{C}$ and $2.0 \mathrm{~h}$

It is known that monosaccharides (glucose, fructose) decompose, producing not only volatile carboxylic acids, but also undergo dehydration and fragmentation reaction producing furfural-derived compounds (furfural, HMF). According to Kabyemela et. all. [45], the reaction mechanism/pathway of Cellobiose decomposition in sub and supercritical $\mathrm{H}_{2} 0\left(300{ }^{\circ} \mathrm{C} / 25 \mathrm{MPa}, 350{ }^{\circ} \mathrm{C} / 25 \mathrm{MPa}, 350{ }^{\circ} \mathrm{C} / 40 \mathrm{MPa}\right.$, and $\left.400{ }^{\circ} \mathrm{C} / 40 \mathrm{MPa}\right)$, fallows the sequence: hydrolysis of Cellobiose to form glucose, followed by pyrolysis to form glycosylerythrose and glycosyl-glycol-aldehyde, which undergo hydrolysis to produce erythrose + glucose/fructose and glycol-aldehyde + glucose/fructose, that is, glucose/fructose are intermediate-reaction products, being produced continuously along the hydrothermal process. However, Hoekman et. all. [43], reported that concentrations of glucose/xylose and total sugars decrease with increasing process temperature $\left(215,235,255,275,295{ }^{\circ} \mathrm{C}\right)$ from $1.02 \%$ (wt.) to $0.08 \%$ (wt.) and $1.41 \%$ (wt.) to $0.22 \%$ (wt.), respectively, being not detected at 275 and $295^{\circ} \mathrm{C}$, such that, one may suppose that degradation of monosaccharides (glucose, fructose) are not the only reaction mechanism to produce volatile carboxylic acids by hydrothermal processing of biomass, as glucose, according to Falco et. all. [16], starts to be produced at $140^{\circ} \mathrm{C}$, reaching a maximum at $200^{\circ} \mathrm{C}$, where it begins to decomposes. 


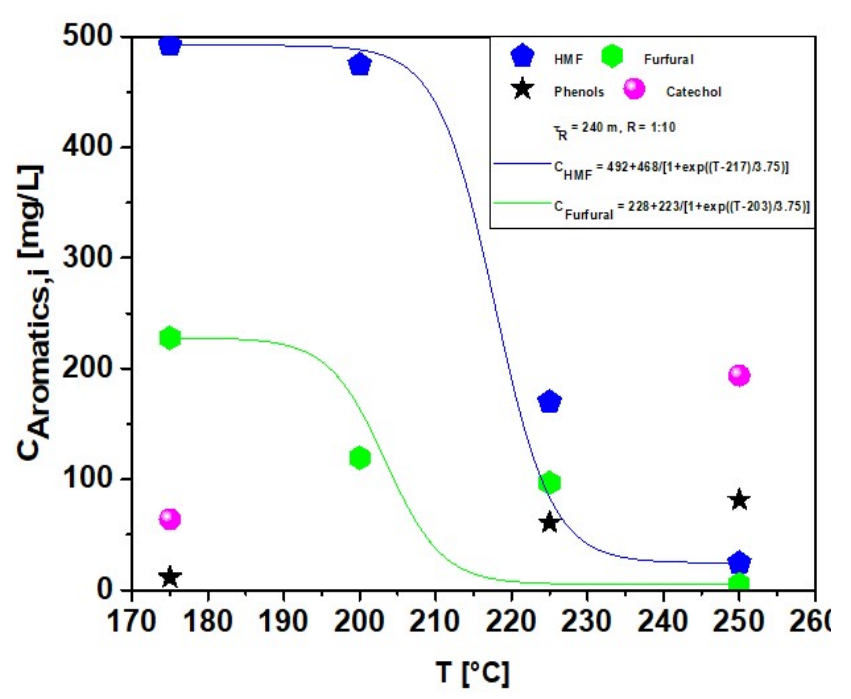

(a)

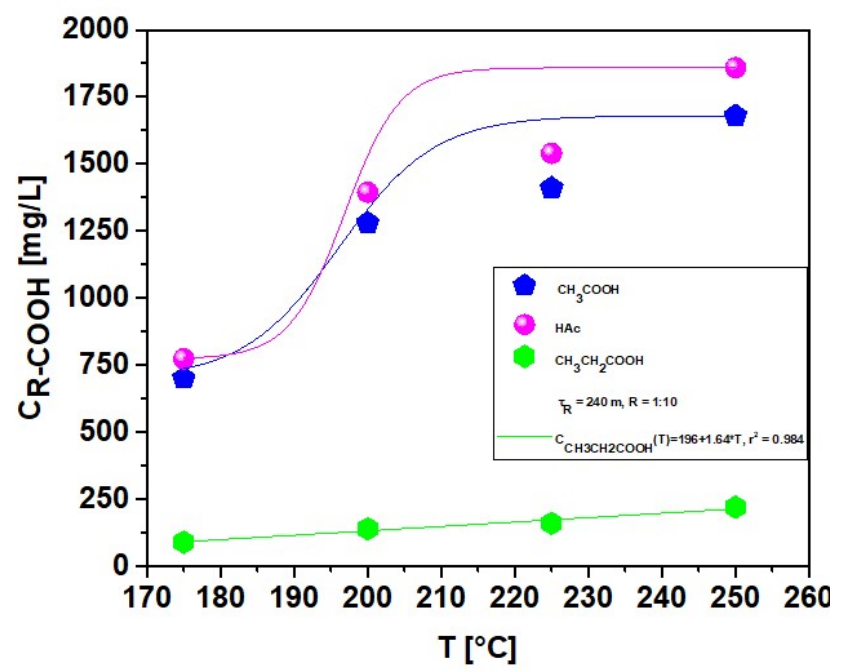

(b)

Figure 6. Effect of temperature on the concentration of aromatic compounds (Phenols, Furfural, HMF, and Cathecol) (a) carboxylic acids $\left(\mathrm{CH}_{3} \mathrm{COOH}, \mathrm{CH}_{3} \mathrm{CH}_{2} \mathrm{COOH}\right)$ and total carboxylic acids (HAc) (b).

The effect of biomass-to-water ratio on the concentration profile of aromatic-ring compounds (Furfural, HMF, Phenols, and Cathecol) and carboxylic acids $\left(\mathrm{CH}_{3} \mathrm{COOH}\right.$, $\mathrm{CH}_{3} \mathrm{CH}_{2} \mathrm{COOH}$ ) by hydrothermal processing of Açaí seeds, illustrated in Figure 7 (a) and (b), and the data summarized in Table 6.

Table 6. Concentration of aromatics compounds (HMF, furfural, phenol, cathecol), carboxylic acids $\left(\mathrm{CH}_{3} \mathrm{COOH}, \mathrm{CH}_{3} \mathrm{CH}_{2} \mathrm{COOH}\right)$ and total carboxylic acids (HAc) in aqueous phase at $25^{\circ} \mathrm{C}$ and 1.0 atmosphere by hydrothermal processing of Açaí seeds with hot compressed $\mathrm{H}_{2} 0$ at 175, 200, 225, 250 ${ }^{\circ} \mathrm{C}, 2{ }^{\circ} \mathrm{C} / \mathrm{min}, 240 \mathrm{~min}$, and biomass-to-water ratio of 1:10.

\begin{tabular}{lccc}
\hline & & $\mathbf{2 5 0}{ }^{\circ} \mathbf{C}$ & \\
\cline { 3 - 4 } & & $\begin{array}{c}\text { Biomass/H20 } \\
{[-]}\end{array}$ & \\
\hline Concentration of aromatics [mg/L] & $\mathbf{1 : 1 0}$ & $\mathbf{1 : 1 5}$ & $\mathbf{1 : 2 0}$ \\
HMF: CAS: 67-47-0 & 24.450 & 5.188 & 3.002 \\
Furfural: CAS:98-01-1 & 5.054 & 2.972 & 2.194 \\
Phenol: CAS: 108-95-2 & 81.24 & 81.78 & 89.33 \\
Catechol: CAS: 120-80-9 & 195.6 & 193.8 & 185.9 \\
Concentration of carboxylic acids [mg/L] & & & \\
Acetic acid: CAS: 64-19-7 & 1680 & 1270 & 1070 \\
Total acetic acid (HAc) & 1859 & 1424 & 1070 \\
Propionic Acid: CAS: 79-09-4 & 220 & 190 & 20 \\
Concentration of alcohols [mg/L] & & & \\
Methanol: CAS: 67-56-1 & $<20$ & $<20$ & $<20$ \\
Ethanol CAS: 64-17-5 & $<20$ & $<20$ & $<20$ \\
Propanol CAS: 71-23-8 & $<20$ & $<20$ & $<20$ \\
Butanol CAS: 71-36-3 & $<20$ & $<20$ & $<20$ \\
\hline
\end{tabular}

By increasing the $\mathrm{H}_{2} \mathrm{O}$-to-Biomass ratio, the concentrations of furfural and HMF are very low and decrease smoothly, while that of phenols shows a smooth first-order exponential growth behavior, as shown in Figure 7 (a). In addition, the carboxylic acids $\left(\mathrm{CH}_{3} \mathrm{COOH}, \mathrm{CH}_{3} \mathrm{CH}_{2} \mathrm{COOH}\right)$ and total carboxylic acids (HAc) also decrease as the $\mathrm{H}_{2} 0$-toBiomass ratio increases, illustrated in Figure 7 (b). In a first look, Figure 7 (a) and (b) do not say much, as the concentration was measured in $\mathrm{mg} / \mathrm{L}$, so that, increasing the $\mathrm{H}_{2} 0$-toBiomass ratio, the volume of reaction media increases, and hence it is to expect a decrease on the concentration of main organic compounds dissolved in process water, but 
performing a mass balance by multiplying the concentration of main organic compounds dissolved in process water, described in Table 6, and the volume of process water (Mass of Liquid Phase $+\Sigma$ Process Loss + Mass of Moist Hydro-char - Mass of Dry Hydro-char Mass of Gas), described in Table 2, it can be shown that increasing the $\mathrm{H}_{2} 0$-to-Biomass ratio has caused an increase on the mass production of chemicals, as shown in Figure 8.

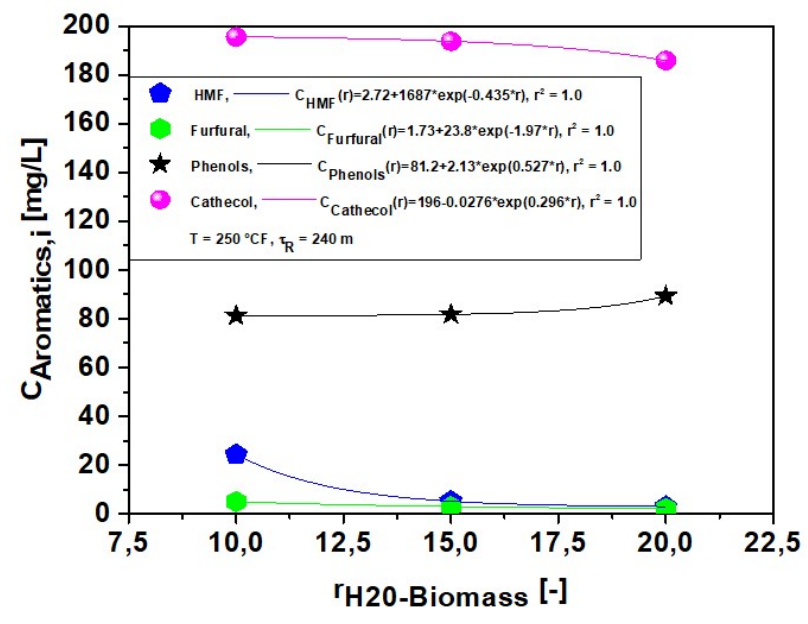

(a)

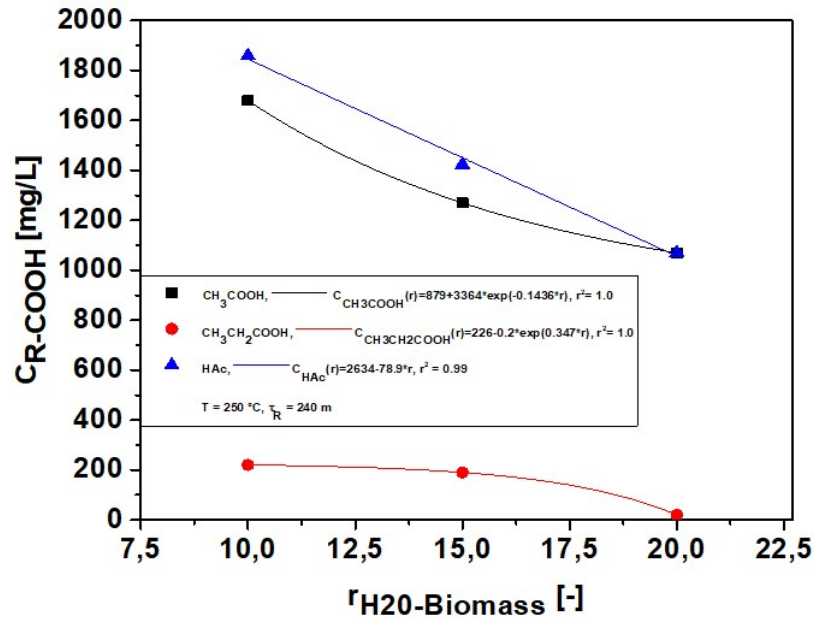

(b)

Figure 7. Effect of $\mathrm{H}_{2} \mathrm{O}$-to-Biomass ratio on the concentration of aromatic compounds (Phenols, Furfural, HMF, and Cathecol) (a) carboxylic acids $\left(\mathrm{CH}_{3} \mathrm{COOH}, \mathrm{CH}_{3} \mathrm{CH}_{2} \mathrm{COOH}\right)$ and total carboxylic acids (HAc) (b).

According to the literature [24-25], increasing the $\mathrm{H}_{2} 0$-to-Biomass ratio causes a great impact on hydrolysis reactions by hydrothermal processing of biomass, so that, the remaining cellulose in biomass is hydrolyzed, producing monosaccharides (glucose, fructose), and the decomposition of monosaccharides (glucose, fructose) produces volatile carboxylic acids, particularly acetic acid, confirmed by Figure 8 (a). It may be concluded that hydrolysis is probably the dominant reaction mechanism, but not the only one, by hydrothermal processing of Açaí seeds with hot compressed $\mathrm{H}_{2} \mathrm{O}$ at $250{ }^{\circ} \mathrm{C}, 2{ }^{\circ} \mathrm{C} / \mathrm{min}, 240 \mathrm{~min}$, as biomass-to-water ratio increase from 1:10 to 1:20.

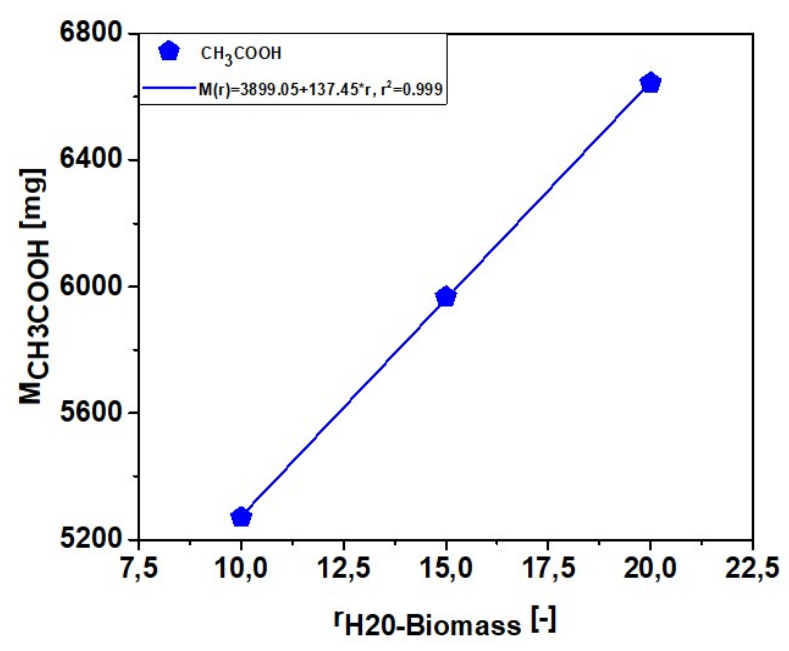

(a)

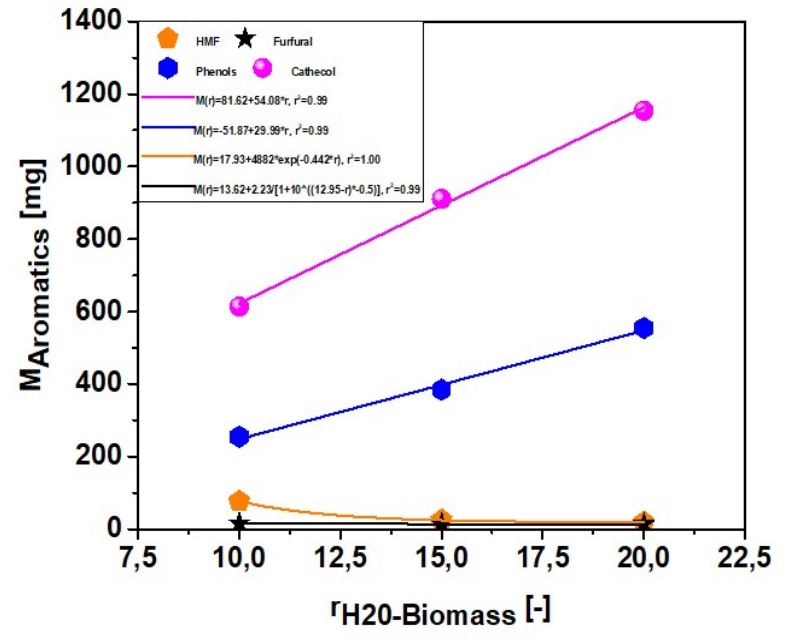

(b)

Figure 7. Effect of $\mathrm{H}_{2} \mathrm{O}$-to-Biomass ratio on the on the mass production of acetic acid $\left(\mathrm{CH}_{3} \mathrm{COOH}\right)$ (a) and aromatic compounds (Phenols, Cathecol) (b). 


\section{Conclusions}

The yield of solids shows a smooth first-order exponential decay behavior, while that of liquid and gaseous phases a smooth first-order exponential growth. At $175{ }^{\circ} \mathrm{C}$ hydrothermal carbonization takes places, as the main reaction product is a solid [15]. From 200 ${ }^{\circ} \mathrm{C}$, hydrothermal liquefaction occurs, as the maim reaction products are liquids [15].

Based on the centesimal composition of Açaí (Euterpe oleracea Mart.) seeds [12], one may perform a centesimal mass balance to compute the approximate theoretical mass degradation of Açaí seeds at $200{ }^{\circ} \mathrm{C}, 2{ }^{\circ} \mathrm{C} / \mathrm{min}, 240 \mathrm{~min}$, and biomass-to-water ratio of 1:10, obtaining for the solid phase yield $41.01 \%$ (wt.), very close to the experimental value of $39.534 \%$ (wt.), showing a deviation of $3.73 \%$.

The yields of hydro-char and gas decrease with $\mathrm{H}_{2} 0$-to-water ratios, while that of liquid phase increases. Increasing the $\mathrm{H}_{2} 0$-to-Biomass ratio causes a great impact on hydrolysis reactions by hydrothermal processing of biomass.

The presence of high volumetric concentrations of $\mathrm{CO}_{2}$ in the gaseous phase indicates that decarboxylation is probably one of the dominant reaction mechanisms/pathways by hydrothermal processing of Açaí seeds in nature, being according to Li et. all. [35].

The concentrations of furfural and HMF, decreases exponentially, being present at very low concentrations at $250{ }^{\circ} \mathrm{C}$, as temperature increases, while the concentrations of phenols and cathecol increase.

By increasing the $\mathrm{H}_{2} \mathrm{O}$-to-Biomass ratio, the concentrations of furfural and $\mathrm{HMF}$ are very low and decrease smoothly, while that of phenols shows a smooth first-order exponential growth behavior. In addition, the carboxylic acids $\left(\mathrm{CH}_{3} \mathrm{COOH}, \mathrm{CH}_{3} \mathrm{CH}_{2} \mathrm{COOH}\right)$ and total carboxylic acids (HAc) also decrease as the $\mathrm{H}_{2} 0$-to-Biomass ratio increases. Performing a mass balance, it can be shown that increasing the $\mathrm{H}_{2} \mathrm{O}$-to-Biomass ratio has caused an increase on the mass production of chemicals, particularly acetic acid.

It may be concluded that hydrolysis is probably the dominant reaction mechanism, but not the only one, by hydrothermal processing of Açaí seeds with hot compressed $\mathrm{H}_{2} 0$ at $250{ }^{\circ} \mathrm{C}, 2{ }^{\circ} \mathrm{C} / \mathrm{min}, 240 \mathrm{~min}$, as biomass-to-water ratio increase from 1:10 to 1:20.

Supplementary Materials: Table S1: Centesimal and elemental characterization of Açaií (Euterpe oleracea, Mart) seeds in nature, compared to similar studies reported in the literature [1-4].

Author Contributions: The individual contributions of all the co-authors are provided as follows: Conceição de Maria Sales da Silva contributed with formal analysis and writing - original draft preparation, Douglas Alberto Rocha de Castro contributed with formal analysis and writing-original draft preparation, Marcelo Costa Santo contributed with formal analysis and software, Hélio da Silva Almeida contributed with formal analysis, software, and visualization, Ulf Lüder contributed with investigation and validation, Maja Shultze contributed with investigation and methodology, Jan Mumme contributed with funding acquisition, Thomas Hofmann contributed with resources and project administration, and Nélio Teixeira Machado contributed with supervision, conceptualization, and data curation. All authors have read and agreed to the published version of the manuscript.

Funding: This research was partially funded by CNPq-Brazil, grant number: 207325/2014-6.

Acknowledgments: I would like to acknowledge the Department of Postharvest Technology at Leibnitz-Institüt für Agrartechnik Potsdam-Bornin e.V, for the opportunity to research at the Laboratory of Biochar, as well as for providing all the technical support (administrative, infra-structure, analytics) and materials to develop this research.

Conflicts of Interest: The authors declare no conflict of interest.

\section{References}

1. Marcelo Morita Lindolfo; Gilson Sérgio Bastos de Matos; Wendel Valter da Silveira Pereira; Antônio Rodrigues Fernandes. Productivity and nutrition of fertigated açaí palms according to boron fertilization. Rev. Bras. Frutic. vol.42 no.2 Jaboticabal 2020 Epub Apr 06, 2020; https://doi.org/10.1590/0100-29452020601

2. Michael Heinrich; Tasleem Dhanji; Ivan Casselman. Açai (Euterpe oleracea. Mart.) - A phytochemical and pharmacologicalassessment of the species' health claims. Phytochemistry Letters 4 (2011) 10-2111 
3. Sara Sabbe; Wim Verbeke; Rosires Deliza; Virginia Matta; Patrick Van Damme. Effect of a health claim and personal characteristics on consumer acceptance offruit juices with different concentrations of açaí (Euterpe oleraceaMart.). Appetite 53 (2009) 84-9286

4. David del Pozo-Insfran; Carmen H. Brenes; Stephen T. Talcott. Phytochemical Composition and Pigment Stability of Açai (Euterpe oleracea Mart.). J. Agric. Food Chem. 2004, 52, 1539-1545

5. José Dalton Cruz Pessoa; Paula Vanessa da Silva e Silva. Effect of temperature and storage on açaí (Euterpe oleracea) fruit water uptake: simulation of fruit transportation and pre-processing. Fruits, 2007, Vol. 62, 295-302; DOI: $10.1051 /$ fruits:2007025

6. D. R. Pompeu; E. M. Silva; H. Rogez. Optimisation of the solvent extraction of phenolic antioxidants from fruits of Euterpe oleracea using Response Surface Methodology. Bioresource Technology 100 (2009) 6076-6082

7. Felipe Fernando da Costa Tavares; Marcos Danilo Costa de Almeida; João Antônio Pessoa da Silva; Ludmila Leite Araújo; Nilo Sérgio Medeiros Cardozo; Ruth Marlene Campomanes Santana. Thermal treatment of açaí (Euterpe oleracea) fiber for composite reinforcement. Polímeros vol.30 n.1 São Carlos 2020 Epub July 01, 2020

8. Lina Bufalino; Arqueanise Andrade Guimaraes; Breno Marques da Silva e Silva; Rafael Lucas Figueiredo de Souza; Isabel Cristina Nogueira Alves de Melo; Dhimitrius Neves Paraguassu Smith de Oliveira; Paulo Fernando Trugilho. Local variability of yield and physical properties of açaí waste and improvement of its energetic attributes by separation of lignocellulosic fibers and seeds. J. Renewable Sustainable Energy 10, 053102 (2018)

9. Anna Cristina Pinheiro de Lima; Dandara Leal Ribeiro Bastos; Mariella Alzamora Camarena; Elba Pinto Silva Bom; Magali Christe Cammarota; Ricardo Sposina Sobral Teixeira; Melissa Limoeiro Estrada Gutarra. Physicochemical characterization of residual biomass (seed and fiber) from açaí (Euterpe oleracea) processing and assessment of the potential for energy production and bioproducts. Biomass Conversion and Biorefinery, https://doi.org/10.1007/s13399-019-00551-w

10. José Dalton Cruz Pessoa; Marcos Arduin; Maria Alice Martins; José Edmar Urano de Carvalho. Characterization of açaí (E. oleracea) fruits and its processing residues. Braz. arch. biol. technol. vol.53 no.6 Curitiba Nov./Dec. 2010, https://doi.org/10.1590/S1516-89132010000600022

11. Andrezza de Melo Barbosa; Viviane Siqueira Magalhães Rebelo; Lucieta Guerreiro Martorano; Virginia Mansanares Giacon. Characterization of acai waste particles for civil construction use. Revista Matéria, v.24, n.3, 2019, http://dx.doi.org/10.1590/s1517-707620190003.0750

12. D. A. R. de Castro; H. J. da Silva Ribeiro; C. C. Ferreira; L. H. H. Guerreiro; M. de Andrade Cordeiro; A. M. Pereira; W. G. dos Santos; F. B. de Carvalho; J. O. C. Silva Jr.; R. Lopes e Oliveira; M. C. Santos; S. Duvoisin Jr; L. E. P. Borges; N. T. Machado. Fractional Distillation of Bio-Oil Produced by Pyrolysis of Açaí (Euterpe oleracea) Seeds. Fractionation, Editor Hassan Al-Haj Ibrahim: Fractionation, Intechopen ISBN: 978-1-78984-965-3, DOI: 10.5772/intechopen.79546

13. Liang Li; Joseph R. V. Flora; Juan M. Caicedo; Nicole D. Berge. Investigating the role of feedstock properties and process conditions on products formed during the hydrothermal carbonization of organics using regression techniques. Bioresource Technology 187 (2015) 263-274

14. N. T. Machado; D. A. R. de Castro; M. C. Santos; M. E. Araújo; U. Lüderf; L. Herklotz; M. Werner; J. Mumme; T. Hoffmann. Process analysis of hydrothermal carbonization of corn Stover with subcritical $\mathrm{H}_{2} \mathrm{O}$. The Journal of Supercritical Fluids 136 (2018) 110-122

15. M. Möller; P. Nilges; F. Harnisch; U. Schröder. Subcritical water as reaction environment: fundamentals of hydrothermal biomass transformation, ChemSusChem4 (2011) 566-579, http://dx.doi.org/10.1002/cssc.201000341

16. Camillo Falco; Niki Baccile; Maria-Magdalena Titirici. Morphological and structural differences between glucose, cellulose and lignocellulosic biomass derived hydrothermal carbons. Green Chem., 2011, 13, 3273

17. Zhengang Liu; R. Balasubramanian. Hydrothermal carbonization of waste biomass for energy generation Procedia Environmental Sciences 16 (2012) $159-166$

18. S. Kent Hoekman; Amber Broch; Curtis Robbins; Barbara Zielinska; Larry Felix. Hydrothermal carbonization (HTC) of selected woody and herbaceous biomass feedstocks. Biomass Conv. Bioref. (2013) 3:113-126

19. Shuqing Guo; Xiangyuan Dong; Tingting Wu; Caixia Zhu. Influence of reaction conditions and feedstock on hydrochar properties. Energy Conversion and Management 123 (2016) 95-103

20. Gule Teri; Ligang Luo; Phillip E. Savage. Hydrothermal Treatment of Protein, Polysaccharide, and Lipids Alone and in Mixtures. Energy Fuels 2014, 28, 7501-7509

21. A. M. Borrero-López; E. Masson; A. Celzard; V. Fierro. Modelling the reactions of cellulose, hemicellulose and lignin submitted to hydrothermal treatment. Industrial Crops \& Products 124 (2018) 919-930

22. Yongfang Zhang; Wensheng Hou; Hong Guo; Sheng Shi; Jinming Dai. Preparation and Characterization of Carbon Microspheres From Waste Cotton Textiles By Hydrothermal Carbonization. JRM, 2019, vol.7, nº.12, DOI: 10.32604/jrm.2019.07884

23. Ilker Örtürk; Sibel Irmak; Arif Hesenov; Oktay Erbatur. Hydrolysis of kenaf (Hibiscus cannabinus L.) stems by catalytical thermal treatment in subcritical water. Biomass and Bioenergy 34 (2010) 1578-1585

24. S. Román; J.M.V. Nabais; C. Laginhas; B. Ledesma; J.F. González. Hydrothermal carbonization as an effective way of densifying the energy content of biomass. Fuel Processing Technology 103 (2012) 78-83

25. Ekaterina Sermyagina; Jussi Saari; Juha Kaikko; Esa Vakkilainen. Hydrothermal carbonization of coniferous biomass: Effect of process parameters on mass and energy yields. Journal of Analytical and Applied Pyrolysis 113 (2015) 551-556 
26. E. Sabio; A. Álvarez-Murillo; S. Román; B. Ledesma. Conversion of tomato-peel waste into solid fuel by hydrothermal carbonization: Influence of the processing variables. Waste Management 47 (2016) 122-132

27. A. Álvarez-Murillo; S. Román; B. Ledesma; E. Sabio. Study of variables in energy densification of olive stone by hydrothermal carbonization. Journal of Analytical and Applied Pyrolysis 113 (2015) 307-314

28. Steven M. Heilmann; H. Ted Davis; Lindsey R. Jader; Paul A. Lefebvre; Michael J. Sadowsky; Frederick J. Schendel; Marc G. von Keitz; Kenneth J. Valentas. Hydrothermal carbonization of microalgae. Biomass and Bioenergy 34 (2010) 875-882

29. Cyrilla Oktaviananda; Ria F. Rahmawati; Agus Prasetya; Chandra W. Purnomo; Ahmad T. Yuliansyah; Rochim B. Cahyono. Effect of Temperature and Biomass-Water Ratio to Yield and Product Characteristics of Hydrothermal Treatment of Biomass. AIP Conference Proceedings 1823, 020029 (2017); https://doi.org/10.1063/1.4978102

30. Herlian Eriska Putra; Enri Damanhuri; Kania Dewi; Ari Darmawan Pasek. Hydrothermal carbonization of biomass waste under low temperature condition. MATEC Web of Conferences 154, 01025 (2018), https://doi.org/10.1051/matecconf/201815401025

31. Daniele Castello; Andrea Kruse; Luca Fiori. Biomass gasification in supercritical and subcritical water: The effect of the reactor material. Chemical Engineering Journal 228 (2013) 535-544

32. Michela Lucian; Luca Fiori. Hydrothermal carbonization of waste biomass: process design, modeling, energy efficiency and cost analysis, Energies 10 (211) (2017)1-18

33. Funke Axel, Reebs Felix, Kruse Andrea. Experimental comparison of hydrothermal and vapothermal carbonization. Fuel Process. Technol. 115 (2013) 261-269

34. Zhang, H.J. Huang, S. Ramaswamy, Reaction kinetics of the hydrothermal treatment of lignin. Appl. Biochem. Biotechnol. 147 (2008) 119-131

35. Liang Li; Ryan Diederick; Joseph R. V. Flora; Nicole D. Berge. Hydrothermal carbonization of food waste and associated packaging materials for energy source generation. Waste Management 33 (2013) 2478-2492

36. Axel Funke; Felix Ziegler. Hydrothermal carbonization of biomass: A summary and discussion of chemical mechanisms for process engineering. Biofuels, Bioprod. Bioref. 4:160-177 (2010)

37. Janewit Wannapeera; Bundit Fungtammsan; Nakorn Worasuwannarak. Effects of temperature and holding time during torrefaction on the pyrolysis behaviors of woody biomass. Journal of Analytical and Applied Pyrolysis 92 (2011) 99-105

38. M. Sevilla; A. B. Fuertes. The production of carbon materials by hydrothermal carbonization of cellulose. CARBON 47 (2009) 2281-2289

39. Roland Becker; Ute Dorgerloh; Ellen Paulke; Jan Mumme; Irene Nehls. Hydrothermal Carbonization of Biomass: Major Organic Components of the Aqueous Phase. Chem. Eng. Technol. 2014, 37, No. 3, 511-518

40. M. Toufiq Reza; Benjamin Wirth; Ulf Lüder; Maja Werner. Behavior of selected hydrolyzed and dehydrated products during hydrothermal carbonization of biomass. Bioresource Technology 169 (2014) 352-361

41. Roland Becker; Ute Dorgerloh; Mario Helmis; Jan Mumme; Mamadou Diakité; Irene Nehl. Hydrothermally carbonized plant materials: Patterns of volatile organic compounds detected by gas chromatography. Bioresource Technology 130 (2013) 621-628

42. Dennis Jung; Michael Zimmermann; Andrea Kruse. Hydrothermal Carbonization of Fructose: Growth Mechanism and Kinetic Model. ACS Sustainable Chem. Eng. 2018, 6, 13877-13887

43. Hoekman, S.K.; Broch, A.; Robbins, C. Hydrothermal carbonization (HTC) of lignocellulosic biomass. Energy Fuels 25(4), 18021810 (2011)

44. Juergen Poerschmann; Barbara Weiner; Robert Koehler; Frank-Dieter Kopinke. Hydrothermal Carbonization of Glucose, Fructose, and Xylose-Identification of Organic Products with Medium Molecular Masses. ACS Sustainable Chem. Eng. 2017, 5, 6420-6428

45. B. M. Kabyemela; M. Takigawa; T. Adschiri; R. M. Malaluan; and K. Arai. Mechanism and Kinetics of Cellobiose Decomposition in Sub- and Supercritical Water. Ind. Eng. Chem. Res. 1998, 37, 357-361

46. Silvia Román; Judy Libra; Nicole Berge; Eduardo Sabio; Kyoung Ro; Liang Li; Beatriz Ledesma; Andrés Álvarez; Sunyoung Bae. Hydrothermal Carbonization: Modeling, Final Properties Design and Applications: A Review. Energies 2018, 11, 216; doi:10.3390/en11010216

47. Johnatt A. R. Oliveira; Andrea Komesu; Rubens Maciel Filho. Hydrothermal Pretreatment for Enhancing Enzymatic Hydrolysis of Seeds of Açaí (Euterpe oleracea) and Sugar Recovery. CHEMICAL ENGINEERING TRANSACTIONS VOL. 37, 2014, 785792

48. Standards T. Acid-Insoluble Lignin in Wood and Pulp. Tappi Method T 222 Om-06. Atlanta, GA: Tappi Press. 2006

49. Buffiere P; Loisel D. Dosage des fibres Van Soest. Weened, Laboratoire de Biotechnologie de l'Environnement. INRA Narbonne. 2007:1-14 